\title{
微細構造の三次元的な理解による灰色植物の分類体系の実現を目指して
}

\author{
高橋紀之 ${ }^{1}$, 野崎久義 ${ }^{1}$ \\ 1 東京大学大学院理学系研究科生物科学専攻 \%113-0033 東京都文京区本郷 7-3-1
}

要旨：灰色植物は一次植物の最も原始的な形態を保持する系統群として全ゲノム解析を含めた研究が実施されているが, 分類学的研究は他の 2 系統である緑色植物や紅色植物に比べ大きく遅れをとってきた。微細藻類の種を形態的に認識する には電子顕微鏡レベルの情報が有用と考えられるが，灰色植物においては，断片的な情報しか得られない従来の電子顕 微鏡法だけでは，光学顕微鏡を超えた微細構造上の分類形質の発見は困難であった。そこで我々は特に原形質体表層の外 被構造に着目し，次世代の超微細形態観察を含む複数の電子顕微鏡法による観察を実施した。電界放出形走査電子顕微鏡 (FE-SEM) と透過電子顕微鏡（TEM）を併用した詳細な形態観察によって, 灰色植物の一種であるCyanophora属において は，細胞表面全体を覆う嶺により緑どられた模様が認められ，この嶺は細胞膜を裏打ちする小葉状の扁平小胞の境界にお ける反り上がりによって形成されていることがわかった。またこの様な微細構造の差異により, Cyanophora biloba と新種 C. sudaeを識別することができた。一方，厚い細胞壁で覆われた Glaucocystis 属の細胞外被は, FE-SEMで直接比較するの は困難であり，超高圧電子顕微鏡による三次元 (3D) 観察を試みた。この結果，Cyanophora と同様の Glaucocystisの細胞膜 と扁平小胞の立体配置が描出され，さらにこの3D微細構造の多様性が明らかになった。これらの結果から，2属に共通す る「細胞膜の内側で小葉状の扁平小胞が密に裏打ちする」外被立体微細構造をもつCyanophora様の鞭毛虫こそが灰色植物 の共通祖先の姿であり, 更には最初の一次植物にまで遡るとも推測された。

\section{Toward the establishment of glaucophyte taxonomic system based on the three- dimensional recognition of ultrastructures}

\author{
Toshiyuki Takahashi ${ }^{1}$, Hisayoshi Nozaki ${ }^{1}$ \\ ${ }^{1}$ Department of Biological Sciences, Graduate School of Science, University of Tokyo, 7-3-1 Hongo, Bunkyo-ku, Tokyo, 113-0033 Japan \\ Author for correspondence: T. Takahashi, tosijuci@bs.s.u-tokyo.ac.jp
}

\begin{abstract}
Summary: Glaucophytes are one of the three major lineages of primary photosynthetic eukaryotes (Archaeplastida), together with red algae and Chloroplastida (green algae and embryophytes). Within Archaeplastida, glaucophytes are thought to retain ancestral features of the first photosynthetic eukaryote. The biflagellate glaucophyte genus Cyanophora has been widely studied as a model organism of primitive phototrophs, with released nuclear genome sequence, but no morphological study has clearly shown ultrastructural diversity to delimit glaucophyte species. Recently, we applied advanced electron microscopic (EM) methodologies for comparative morphology in a purpose of delineating the glaucophyte species. On the basis of ultra-high resolution field emission scanning EM (FE-SEM), we demonstrated that the cell surface of Cyanophora was ornamented with angular fenestrations framed by ridges. As supported by observation using several transmission EM methods, these ridges were formed by the edges of overlapping or attaching outermost plate vesicles that distributed throughout the cell periphery just underneath the cell membrane. Based on differences in the pattern of surface ornamentations detected by FE-SEM, Cyanophora biloba and C. sudae were distinguished from each other. FE-SEM, however, cannot be applied for the native protoplast surfaces that are enclosed by a thick cell wall or extracellular matrix as in the immotile glaucophyte genus Glaucocystis. Alternatively, we very recently used the advanced ultra-high voltage EM tomography to unveil the in situ peripheral ultrastructure of protoplasts in Glaucocystis and revealed the ultrastructural diversity in this genus. Furthermore, Glaucocystis cells have numerous, leaflet-like flattened vesicles distributed throughout the protoplast periphery just underneath the cell membrane, as in Cyanophora as well as some secondary photosynthetic eukaryotes. Thus, a similar 3D peripheral ultrastructure might have appeared in the common ancestor of glaucophytes and/or the first photosynthetic eukaryote.
\end{abstract}

Key words: Cyanophora, flattened vesicles, field emission scanning electron microscopy, Glaucophyta, taxonomy, ultrastructure

\section{はじめに}

現生の一次植物 Archaeplastida (Adl et al. 2005, 2012)，ま たは植物界Plantae sensu Caval.-Sm. (1981) は, 10-20億年 前の中原生代頃に起きた，光合成を行わない原生生物に 光合成細菌シアノバクテリアが取り込まれ色素体となっ た，一次共生と呼ばれるイベントによって成立したと考え られている (Sagan 1967)。このような一次植物は3つの系 統群からなるのだが, この内, 紅色植物が広く海洋に分布
し, 緑色植物が陸上に迄進出しているのに対し, 残る灰色 植物 (図 1) は単細胞〜群体性の淡水産微細藻の稀産種が 20 種程度知られているに過ぎない (Kies 1992)。しかし，灰 色植物は色素体の色素組成や形態がシアノバクテリアに極 めて類似しており, 一次植物の最も原始的な形態を保持す る系統群として葉緑体分裂の研究や全ゲノム解析が実施さ れている (e.g., 佐藤ら 2009, Sato et al. 2009, Price et al. 2012, Spiegel 2012). 
このように灰色植物は，一次植物の起源を研究する上で 重要であると考えられる。しかし, 複雑な多細胞体が進化 している紅色植物と緑色植物に関しては, Linnaeus (1753) 以前から既に多くの研究者によって様々な手法で種レベル の分類が行われてきた (e.g., 李 1596)のに対して, 灰色植 物の種レベルの分類は今日まで大きく立ち遅れていた。灰 色植物の種分類学的研究では野外試料を直接用いた光学顕 微鏡観察・記載が中心で, クローン株レベルの形態学的多 様性については殆ど研究されておらず，分子情報も用いら れていなかった (Takahashi et al. 2014a). 灰色植物の微細 構造の研究はいくつかあったが, 微細構造上の差異につい ては殆ど報告されていなかった。そこで我々は灰色植物の 客観的かつ全世界レベルの種レベルの分類体系を構築する ことを目的とし, 再現性のある材料として世界の株保存機 関の保存培養株を入手し，独自に確立した新規株を加え て, 分子系統解析と比較形態観察を実施した (Takahashi et al. 2014a). 形態比較では光学顕微鏡観察と従来の電子顕 微鏡による観察に加え, 近年生物学に応用され始めた新し い電子顕微鏡法による比較観察を実施した (Takahashi et al. 2014a, 2014b, 2015). 最新の電子顕微鏡機器を用いることで, 微細な灰色植物であっても巨視的な植物と同様に形態学的 に種が分類できると期待したからである。特に原形質体表 層の外被構造に着目した形態比較の結果，種を識別する微 細構造上の形態的多様性が灰色植物 2 属 (図 1) で明らかと なった。

\section{Cyanophora属の分類学的問題点}

Kies and Kremer (1986)によれば，灰色植物は灰色植物門 Glaucophyta 灰色藻綱 Glaucophyceaeから構成され, 鞘被性, 厚膜球状, 遊泳性という大きく異なる形態形質によって3 目に分類されている.Cyanophora属 (図 1) は単細胞遊泳性 の目 Cyanophorales に所属し, C. paradoxa, C. tetracyanea, C. bilobaの3 種が記載されていた (Kugrens et al. 1999). 本属 のなかで種の原記載で用いられた培養株 (正統株) が維持
されていたのはC. biloba（UTEX 2766）のみであり, 他の 2 種の原記載は野外試料の光顕観察だけに基づいていた。こ れら 2 種と表示されている保存株は存在するが, 培養株を 用いた形態情報と分子情報に基づく種分類学的な研究は行 われていなかった(Takahashi et al. 2014a)。そこで我々は $C$. biloba正統株を含む本属と表示されている保存株7株を世 界各地から入手し用いた. 更に, 本州各地から野外試料を 採取し, 土壌浸出法によって新規株の確立を試みた結果, 奈良県生駒市の土壤試料から Cyanophora属の新規培養株 を確立することに成功したため，合わせて用いた。

\section{Cyanophora 属の光顕観察}

培養株の光顕レベルの形態比較を実施した結果, 単細 胞性のCyanophora属にも明瞭な識別点が存在した（図2, Takahashi et al. 2014a). 腹側から見て細胞の中央に深い溝 が走り左右の両葉に分かれる双葉性の株 (図 2E-H) と, こ の様な葉の分化の見られない単葉性の株 (図2A-D) とに分 類された. 分子系統解析の結果 (図3), この葉の有無は Cyanophora属を系統的に 2 分する形態的特徵であることが 分かった.

双葉群では, 新種 C. sudae が成熟細胞の色素体の数が通 常4個であり (図 2E), 通常 2 個のC. biloba (図 2G) と区別 されるが, 色素体の数は変異があり, また他の点で両種を 更に明確に識別するのは光学顕微鏡レベルの情報だけでは 困難であった。

単葉群内の分類はさらに難航を極めた。分子情報から は複数の隠蔽種を含む程度の遺伝的多様性が存在すると 示唆されたにもかかわらず，すべての株が基本的には $C$. paradoxa としか同定できなかった. 双葉群で比較的安定し ていた色素体の数や分裂様式も単葉群ではクローン株内で 非常にばらついていた。 また, 単葉群では細胞の形状につ いても光学顕微鏡のみで種レベルの差異を明らかにするこ とはできなかった。

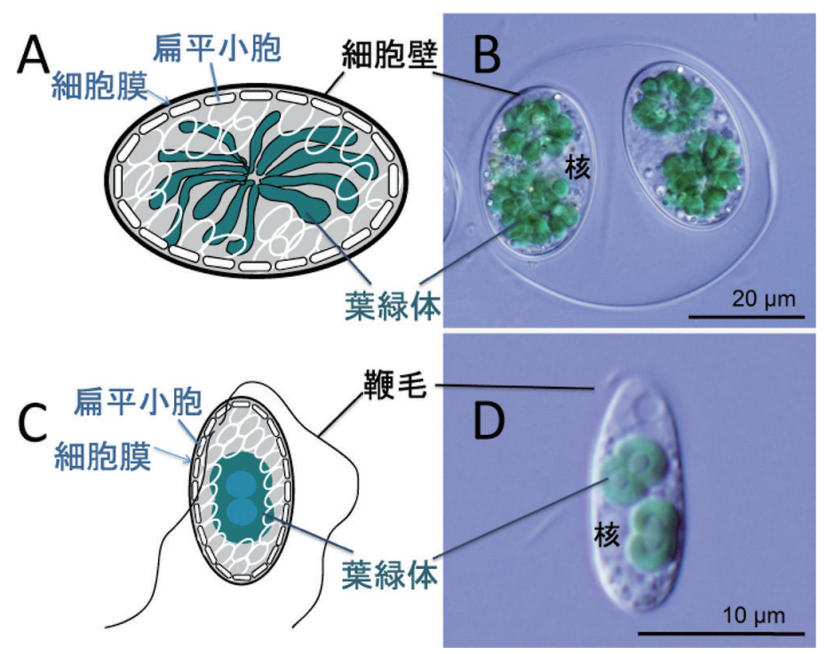

図 1 Cyanophora属 (A, B) と Glaucocystis 属 (C, D) の模式図 (A, C) と微分干渉光学顕微鏡写真 $(B, D)$.
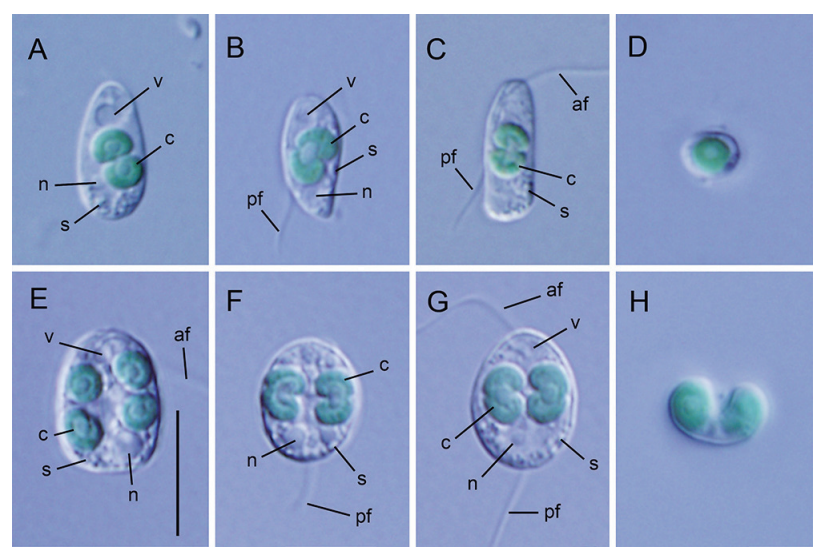

図 2 Cyanophora属 5 種の微分干涉光学顕微鏡写真. Bar $=10 \mu \mathrm{m}$. $\mathrm{af}=$ 前鞭毛 $; \mathrm{pf}=$ 後鞭毛 $; \mathrm{c}=$ 色素体 $; \mathrm{n}=$ 核 $; \mathrm{s}=$ 澱粉粒 $; \mathrm{v}=$ 収縮胞. (A) C. paradoxa の側方観. (B, D) 新種 C. cuspidata の側方観 (B) と 横断面 (D). (C) 新種 C. kugrensii の側方観. (E, F, H) 新種 C. sudae の色素体が4個の側方観 (E), 色素体が 2 個の側方観 (F), 横断面 (H). (G) C. biloba の側方観. Takahashi et al. (2014a) より転用した. John Wiley and Sons の転載許可による (License Number: 3771700412358). 


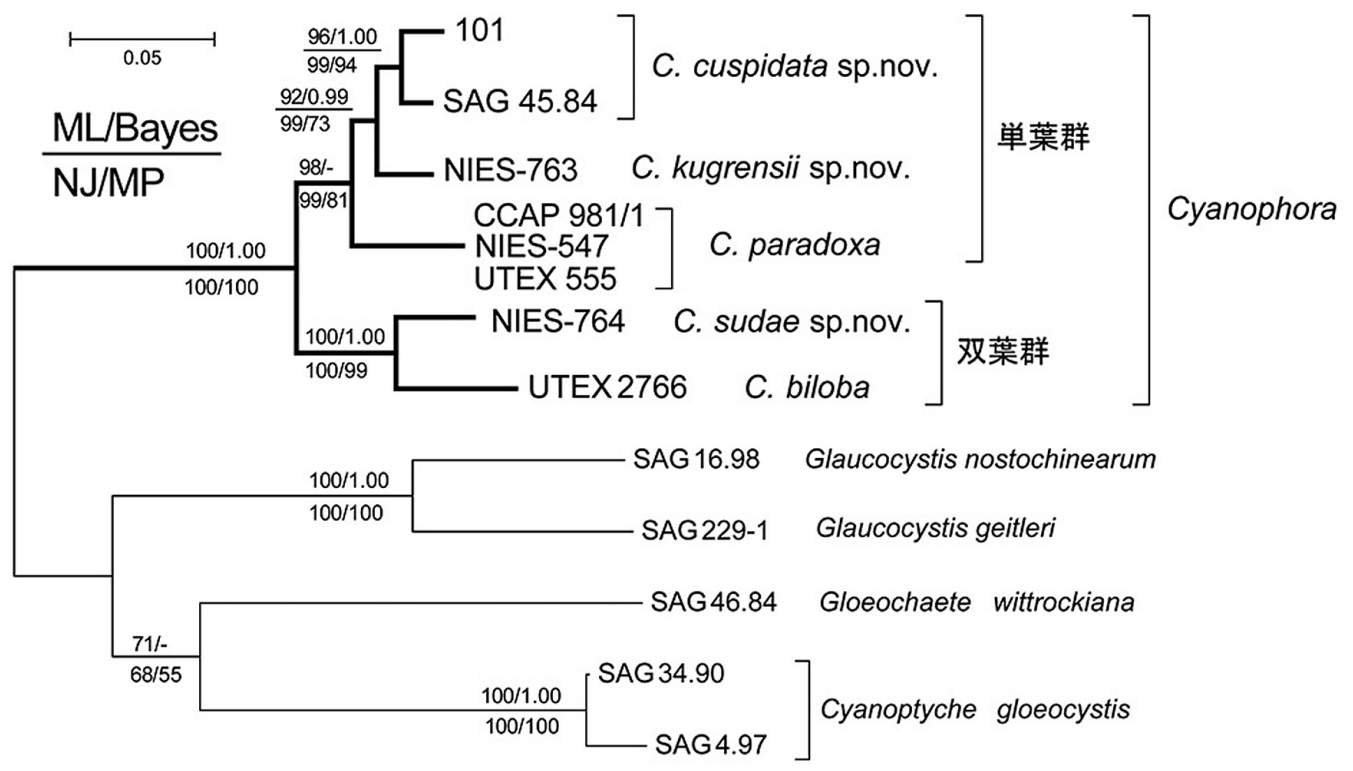

図3 psaB 最尤法系統樹.Cyanophora 5 種は形態で認識できる単葉群・双葉群に分かれた。Takahashi et al. (2014a) より引用・改変した. John Wiley and Sons の転載許可による (License Number: 3771700412358).

\section{Cyanophora 属の電界放出形走查電子频微鏡観察}

Cyanophora は細胞壁をもたず，プレートを包んだ扁平 小胞であるプレート小胞が細胞膜を裏打ちする細胞外被を もつことは知られていたが, 従来の走査電子顕微鏡 $(\mathrm{SEM})$ では細胞表層の微細構造は明らかではなかった (Kugrens et al. 1999). 我々はSEM観察の条件検討を行ない，低加 速電圧での観察でC. paradoxaの細胞外被表面の微細構造 を明らかにすることに成功した (図4A-C, Takahashi et al. 2014b). しかし汎用SEMでは殊に低加速電圧域で分解能 が低かったため (図 4B，C), 低加速電圧でも高解像度の観 察が可能な超高分解能電界放出形走査電子顕微鏡 (FE-SEM) による表面観察を実施した (図4D，E)。この結果，細胞表 面全体を覆う, 嶺により縁どられた模様が認められた。超 薄切片透過電子顕微鏡 (TEM) 観察により, 嶺はプレート 小胞の境界における反り上がりによって形成されているこ とが分かった。 そこでこの低加速電圧 FE-SEM 法と超薄切 片TEMによる形態比較を全株で行なった(図5). その結果, この様な外被微細構造はCyanophora属に共通する特徴で あることが分かった (Takahashi et al. 2014a).

双葉群において細胞背側でこの表面の模様を比較した ところ，C. bilobaで4〜 5角形〜扇型であるのに対し，C. sudaeでは5〜6角形の八ニカム構造様であった (図 5D, E). フリーズフラクチャ(凍結割断) TEMによって細胞膜を剥 がして観察した結果，SEMで観察される外被の模様が内 部のプレート小胞の形態を反映していることが明らかとなっ た(図6).

単葉群6株のなかで, 新種C. cuspidataではしばしば細 胞後端が非常に鋭く尖った尾を有する点で区別できた(図 5B, G).この尾は光顕レベルでは多様な細胞形状の中で 認知する事が困難であった形質であったが，低加速電圧 FE-SEM法では非常に鋭利であり，本種に固有である事が 明瞭に示された。更に光顕と異なり細胞の輪郭が明瞭な SEM写真上で詳細な細胞形状として多数の個体の細胞長
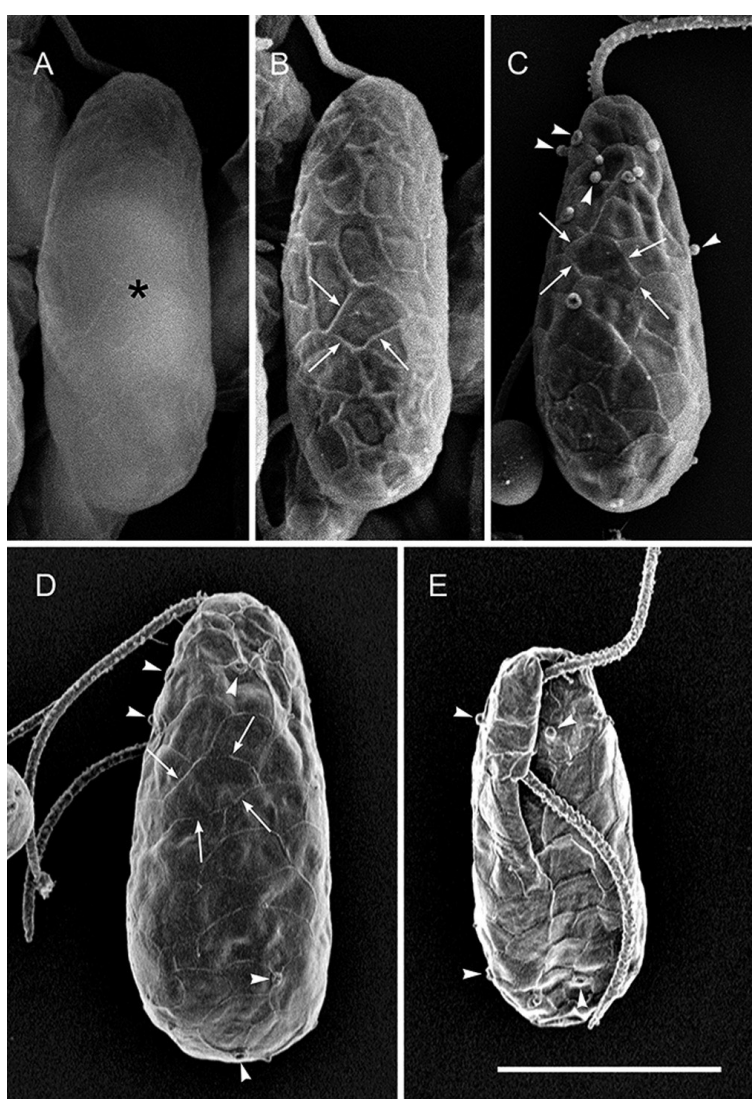

図4Cyanophora paradoxaの走査電子顕微鏡 (SEM) 法の比較. Bar $=5 \mu \mathrm{m}$. (A) 四酸化オスミウム単固定, 汎用 SEM像, 加速電圧 15 $\mathrm{kV}$. (B) 四酸化オスミウム単固定, 汎用 SEM像, 加速電圧 $5 \mathrm{kV}$. 低加速電圧で表面構造が現れた。(C) 四酸化オスミウム・グルター ルアルデヒド二重固定，汎用 SEM像，加速電圧 $5 \mathrm{kV}$. 固定法をよ りマイルドなものとする事でアーティファクトの少ない構造が観 察できた。（D, E) 四酸化オスミウム・グルタールアルデヒド二重固定, 電界放出形 (FE-) SEM像, 加速電圧 $1 \mathrm{kV}$. 低加速電圧 FE-SEM 法 によって, 嶺で囲まれた模様が鮮明に観察できた. Takahashi et al. (2014b)より転用した。 日本メンデル協会の転載許可による. 
や幅を測定したところ，統計的な形態差が認められた。C cuspidataで細胞形状が広長球〜広倒卵球形であったのに 対し, C. paradoxaで広卵球形, 新種 C. kugrensiiで狭卵球 形である点で相互に区別でき，単葉群は 3 種に分類される ことが明らかになった(図 3,5$)$.

以上のように様々な電子顕微鏡法を併用することで, Cyanophora属に共通する外被の立体微細構造が推測され

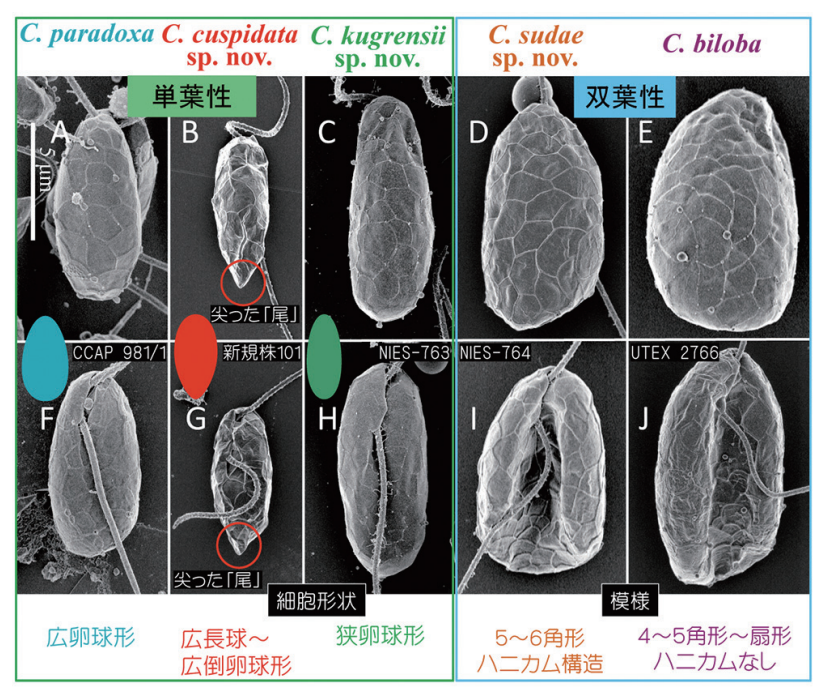

図 5 Cyanophora属 5 種の電界放出形走査電子顕微鏡写真. Bar $=$ $5 \mu \mathrm{m}$. (A, F) C. paradoxa. (B, G) 新種 C. cuspidata. ( $(\mathrm{C}, \mathrm{H})$ 新種 $C$. kugrensii. (D, I) 新種C. sudae. 模様は 5 6 角形で八二カム構造様. (E, J) C. biloba. 模様は 4 5角形〜扇型. Takahashi et al. (2014a) より引用・改変した. John Wiley and Sons の転載許可による (License Number: 3771700412358).
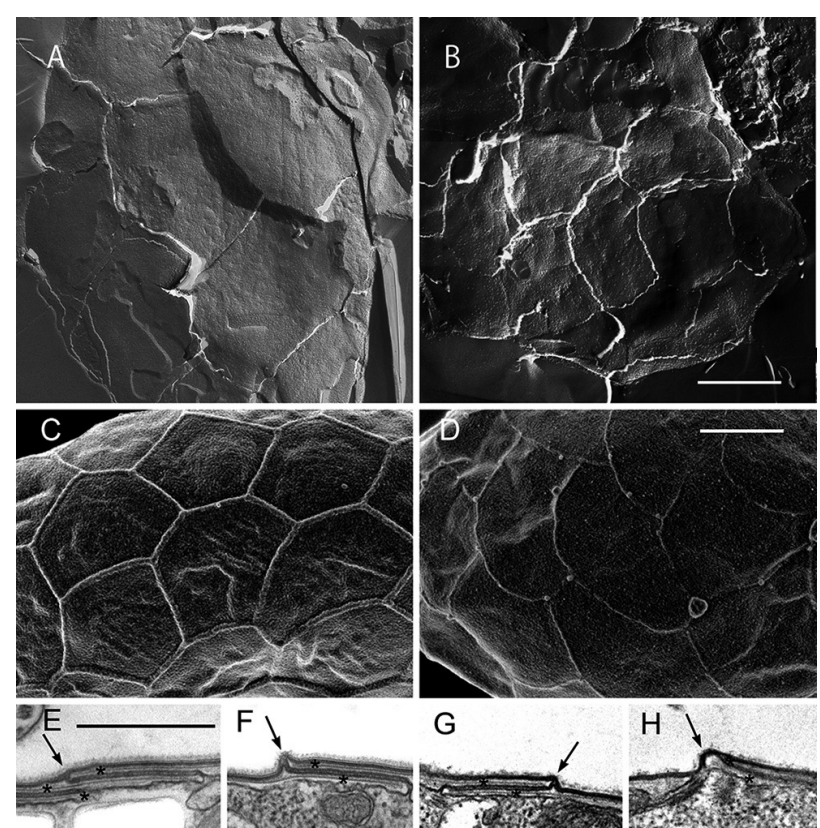

図6 フリーズフラクチャ透過電子顕微鏡 $(\mathrm{TEM})(\mathrm{A}, \mathrm{B})$, 電界放 出形走查電子顕微鏡写真 $($ C, D ) と超薄切片 TEM (E-H). 細胞表面 全体を覆う模様は嶺により緑どられるが, 嶺はプレート小胞の境 界における反り上がりによって形成され, 模様は内部のプレート の形態を反映していた. Bar $=1 \mu \mathrm{m}$. (A, C, E, F) 新種 C. sudae. (B, D, G, H) C. biloba. Takahashi et al. (2014a) より引用・改変した. John Wiley and Sons の転載許可による (License Number: 3771700412358).
た (Takahashi et al. 2014a, 2014b).Cyanophora属 5 種は細胞 膜全体を小葉状のプレート小胞が裏打ちしており, 低加速 電圧FE-SEM で直接, 細胞全体を覆う小葉状の扁平小胞の 模様を捉えることができた. Cyanophora属が細胞膜表面 に嶺で囲まれた模様というダイナミックな構造を有してい るとは思いもよらなかったので, 観察している我々にとっ ては驚きであった。そしてこの事が更なる灰色植物の外被 観察を行なう契機ともなった。

一方, 我々の分類学的研究によってCyanophora属には 従来の 2 倍にも相当する種が存在する事が明らかになった。 この事はこれ迄非常に小さな系統群とされてきた灰色植物 にも光顕レベルで判別が難しい未記載種がかなり存在する 事を示唆した.この中で低加速電圧FE-SEM法による比較 形態学的な観察は, 種を識別する分類形質を発見するのに 有効であり, この手法により細胞全体を観察できる利点を 活かし新種 C. cuspidata や新種 C. sudae に特徵的な微細構 造レベルの識別点が明らかとなった。低加速電圧FE-SEM ではより高倍率の観察も可能であり, 実際, 模様内側の平 坦な細胞膜表面のナノスケールのざらつきに種間差が認め られたのだが, 現状では分類形質として採用していない. 今後 Cyanophora 属の培養株の確立に伴って更に詳細な外 被観察を行なう事で, このスケールの形質による分類へと 進展するかも知れない。

\section{Glaucocystis属の分類学的問題点}

Glaucocystis 属は Glaucocystales に分類される不動厚膜球 状性の灰色植物 (図1) であり, これまでにおもに野外試料 の光学顕微鏡観察をもとに約 6 種が認められていた (Komárek and Fott 1983). 本属においては複数の培養株のTEMによ る比較が行われていたが, 微細構造上の違いはないと報告 されていた (Schnepf et al. 1966). 近年, 我々の研究と並行 してChongら (2014) は培養株のマーカー遺伝子を用いて 本属に隠蔽種とも考元られる遺伝的多様性を報告している が，種を識別するような形態形質については報告していな い. ごく最近我々は Glaucocystis属の複数の培養株を用い た微細構造レベルの形態比較を実施しており, その一部を 以下に紹介したい.

\section{Glaucocystis 属細胞外被の超高圧電子顕微鏡観察}

Glaucocystis 属の外被構造については, G. geitleriを用い た超薄切片TEM観察が実施されており，Cyanophoraに類 似した細胞膜を裏打ちするプレート小胞の存在が示唆され ていた (Schnepf et al. 1966). 一方, G. geitleriのフリーズ フラクチャ TEMでは, アピコンプレックサ (寄生性アルベ オラータ) と類似した 3 重の細胞膜からなる外被モデルが 提出されており (Robinson and Preston 1971), 細胞周期の ステージによって変わるという説も提唱されていた (Willison and Brown 1978).

Glaucocystis属においてもCyanophora属と同様に細胞 外被に種を識別する多様性があると我々は期待したが, Glaucocystis属は厚い細胞壁で囲まれその中で自殖するの で, FE-SEMによる直接比較はできない.このため本属で は代替的なアプローチが求められた。 そこで我々はこの外 被構造を丸ごと立体的に微細構造レベルで観察するため に, 超高圧電子顕微鏡を用いることとした (Takahashi et al. 
2015). 超高圧電子顕微鏡は超高加速電圧を用いることで 厚い試料の透過観察が可能な TEMの一種であり, X線 CT スキャンのように, 回転撮影した試料の透過像シリーズか ら再構築することで断層像シリーズであるトモグラフィー を得ることが可能である. 超高圧電子顕微鏡トモグラフィー は近年, 生物試料にも応用されているが, これまでに分 類学的研究に応用されたことはなかった。そこで我々は Glaucocystis属の 2 種, G. nostochinearum と G. geitleriの培 養株を用いて, 微細構造の保存性の良好な固定法である加 圧凍結・凍結置換法によって作成した樹脂試料を超高圧電 子顕微鏡で観察し, トモグラフィーによる3 次元微細構造 レベルの形態比較を試みた (Takahashi et al. 2015).

この結果, 細胞壁内側の細胞外被を立体微細構造レベル で直接観察することができ, 必要な情報のみを輪郭抽出に よって3Dイメージとして示した(図7). Glaucocystis属2 種においても, 細胞膜の内側全体を小葉状の扁平小胞が裏 打ちする細胞外被構造を有することが解明され，この細胞 外被構造には種多様性が存在することが明らかになり, 今 後の本属の種分類に大きく貢献することが期待された(図 8 ).

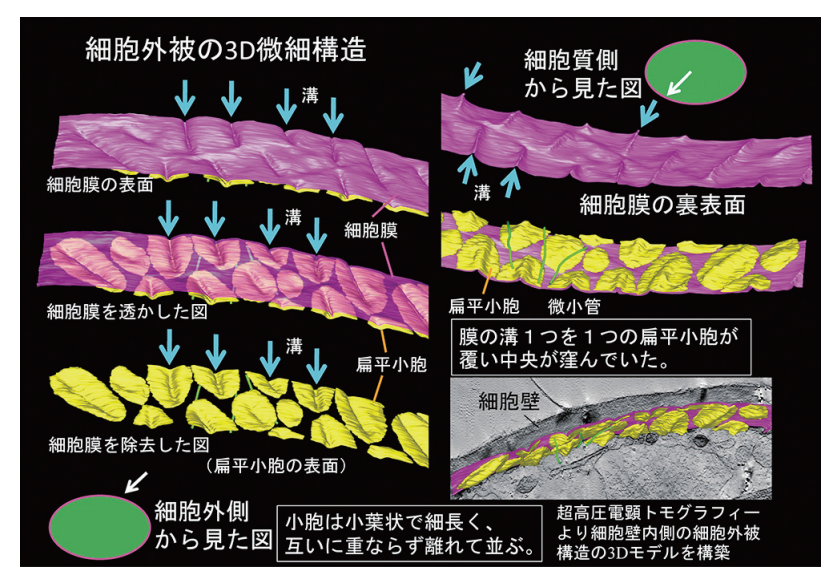

図 7 G. geitleri の超高圧電子顕微鏡トモグラフィーと3Dイメージ ング. Takahashi et al. (2015)より引用・改変した.

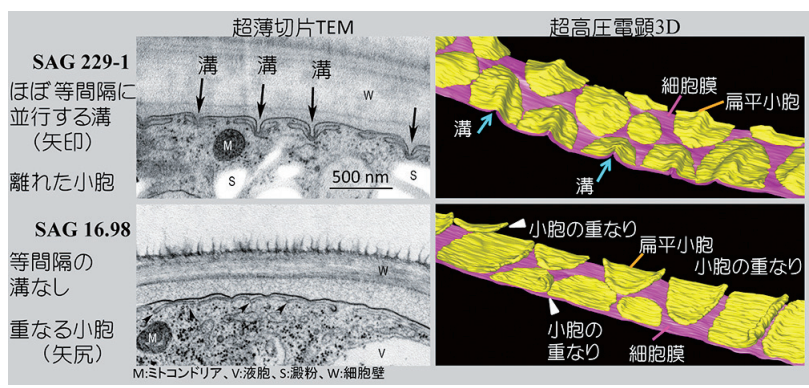

図 8 Glaucocystis 外被微細構造の多様性。超高圧電子顕微鏡3D (右)で解明されたGlaucocystis 培養株の細胞外被3D微細構造には 多様性が認められ, 超薄切片透過電子顕微鏡 (左)でも区別された. Takahashi et al. (2015) より引用・改変した.

\section{遙かなる一次植物の旅路}

我々はこれまでに, 灰色植物全体の2大系統を代表す る (Chong et al. 2014) 遊泳性 Cyanophora と不動厚膜球状性 Glaucocystisの両属で, 基本的には同じ「細胞膜の内側で 小葉状の扁平小胞が密に裏打ちする」細胞外被立体微細構 造をもつことを明らかにしてきた（Takahashi et al. 2014a， 2014b，2015).このような細胞外被構造は一次植物の他の 2系統である緑色植物や紅色植物では知られていない。し かし, 系統的に一次植物の外側に位置するとされるアル ベオラータやハプト藻といった二次共生を経験した鞭毛 藻類では知られている (Winter and Siesser 1994, Adl et al. 2012). 特にアルベオラータの 1 種である厚膜球状性光合 成生物 Chromera veliaでは, 細胞表面が模様で覆われてい る遊泳細胞の FE-SEM像が報告されており (Weatherby et al. 2011), 我々が明らかにした Cyanophoraの FE-SEM像と 非常に類似している。さらにChromera veliaの不動栄養細 胞が細胞壁中で自殖して殖える様式 (Moore et al. 2008) は Glaucocystisに類似しており，アルベオラータと灰色植物 の単細胞遊泳性の祖先型からの平行進化であると考元られ る.これらのことから灰色植物の共通祖先が Cyanophora 様の鞭毛虫であって, すでに「細胞膜の内側で小葉状の扁 平小胞が密に裏打ちする」立体微細構造を獲得していた可 能性があり, 更には最初の一次植物にまで遡るとも推測さ れた (図9)。このことは真核生物の Bikontaの大部分であ る外被類 (corticates) と呼ばれるグループが外被構造でまと められるという仮説 (Cavalier-Smith 2010) を支持した。

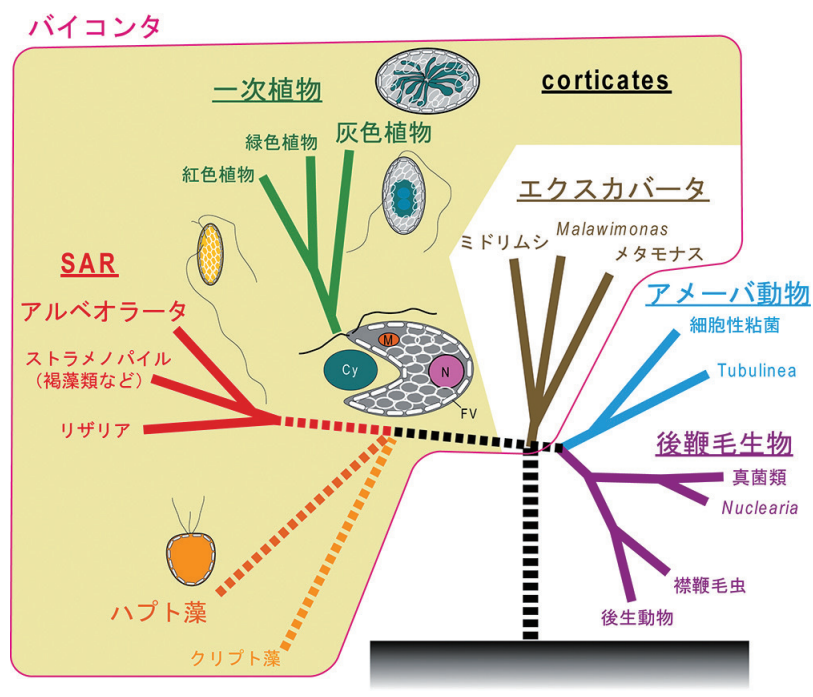

図9 現生の真核生物への外被の進化. 灰色植物の共通祖先は Cyanophora様の鞭毛虫であって, 既に「細胞膜の内側で小葉状 の扁平小胞が密に裏打ちする」立体微細構造を獲得していた可能 性があり, 更には最初の一次植物にまで遡るとも推測された。 Takahashi et al. (2015) より引用・改変した.

\section{灰色植物の種分類のこれから}

低加速電圧FE-SEM法による比較形態学的な観察は, 細 胞表面全体の超高分解能観察が可能で, 微細藻類の種を識 別する微細構造レベルの分類形質を発見するのに有効であっ た. 超高圧電子顕微鏡トモグラフィーは我々の研究で初め て分類学に応用されたが, 細胞の内部であっても3D微細 構造レベルの形態比較が可能であり, 微生物への3D形態 情報の有用性を示した。これらの次世代の超微形態観察は, 断片的な情報しか得られなかった従来の電子顕微鏡観察に 取って代わって今後の微生物分類の主流となると期待され る.このレベルの微細形態比較によって, 灰色植物門全体 の種レベルの多様性が明らかとなり, 本門全体の種分類に 
基づく新しい高次分類体系の構築が実現できるものと考え られる。

\section{謝辞}

本研究を進めるにあたり，共同研究として低加速電圧 SEM 観察法・固定法を丹念に御教授下さった佐藤藏子, 豊 岡公徳両博士 (理化学研究所) には非常に御尽力頂いた. また，フリーズフラクチャ (凍結割断) TEM 観察は高知大 学において川村真依氏, 奥田一雄教授の親切な御指導の 下，共同研究させて頂いた。FE-SEMは日立八イテクのデ モルームのSU8020を利用させて頂き，観察に際して檀紫氏， 渡邊俊哉氏に御助力頂いた。藻類サンプリングでは川舩か おる博士 (東京工業大学) にお世話になり，松㠃令博士 (東 京大学) には微細藻類の取扱いから分子実験まで様々な面 で大変面倒をお掛けした。加圧凍結・凍結置換法は齊藤知 恵子博士 (現 JST) に御指導頂き, 東大農学部加圧凍結装置 HPM010利用に際して石綱史子氏に御助力頂いた。超高圧 電子顕微鏡観察では大阪大学超高圧電子顕微鏡センターで 西田倫希博士 (現QTEC), 保田英洋教授と共同研究させて 頂いた．本稿で紹介した研究成果はこれら各方面の専門家 の御援助があって初めて実現できたものであり，この場を 借り深謝の意を表明したい.

\section{引用文献}

Adl, S. M., Simpson, A. G. B., Farmer, M. A., Andersen, R. A., Anderson, O. R., Barta, J. R., Bowser, S. S., Brugerolle, G., Fensome, R. A., Fredericq, S., James, T. Y., Karpov, S., Kugrens, P., Krug, J., Lane, C. E., Lewis, L. A., Lodge, J., Lynn, D. H., Mann, D. G., McCourt, R. M., Mendoza, L., Moestrup, O., Mozley-Standridge, S. E., Nerad, T. A., Shearer, C. A., Smirnov, A. V., Speigel, F. W., and Taylor, M. F. J. R. (2005) The new higher level classification of eukaryotes with emphasis on the taxonomy of protists. J Eukaryot Microbiol 52: 399451.

Adl, S. M., Simpson, A. G. B., Lane, C. E., Lukeš, J., Bass, D., Bowser, S. S., Brown, M. W., Burki, F., Dunthorn, M., Hampl, V., Heiss, A., Hoppenrath, M., Lara, E., le Gall, L., Lynn, D. H., McManus, H., Mitchell, E. A. D., Mozley-Stanridge, S. E., Parfrey, L. W., Pawlowski, J., Rueckert, S., Shadwick, L., Schoch, C. L., Smirnov, A., and Spiegel, F. W. (2012) The revised classification of eukaryotes. J Eukaryot Microbiol 59: 429-514.

Cavalier-Smith, T. (1981) Eukaryote kingdoms: Seven or nine? BioSys 14: 461-481.

Cavalier-Smith, T. (2010) Kingdoms Protozoa and Chromista and the eozoan root of the eukaryotic tree. Biol Lett 6: 342-345.

Chong, J., Jackson, C., Kim, J. I., Yoon, H. S., and Reyes-Prieto, A. (2014) Molecular markers from different genomic compartments reveal cryptic diversity within glaucophyte species. Mol Phylogenet Evol 76: 181-188.

Kies, L. (1992) Glaucocystophyceae and other protists harbouring procaryotic endocytobionts. In: Reisser W (ed) Algae and symbioses: plants, animals, fungi, viruses, interactions explored, Biopress, Bristol, pp. 353-377.

Kies, L. and Kremer, B. P. (1986) Typification of the Glaucocystophyta. Taxon 35: 128-133.

Komárek, J. and Fott, B. (1983) Chlorophyceae (Grünalgen); Ordnung: Chlorococcales. E. Schweizerbart'sche Verlagsbuchhandlung, Stuttgart.

Kugrens, P., Clay, B. L., Meyer, C. J., and Lee, R. E. (1999) Ultrastructure and description of Cyanophora biloba, sp. nov., with additional observations on C. paradoxa (Glaucophyta). J Phycol 35: 844-854.

Linnaeus, C. (1753) Species plantarum, exhibentes plantas rite cognitas, ad genera relatas, cum differentiis specificis, nominibus trivialibus, synonymis selectis, locis natalibus, secundum systema sexuale digestas. Impensae Laurentii Salvii, Holmia.

李時珍 (1596) 本草綱目. 後学胡承龍梓行, 金陵.

Moore, R. B., Oborník, M., Janouškovec, J., Chrudimský, T., Vancová, M., Green, D. H., Wright, S. W., Davies, N. W., Bolch, C. J. S., Heimann, K., Šlapeta, J., Hoegh-Guldberg, O., Logsdon, J. M., and Carter, D. A. (2008) A photosynthetic alveolate closely related to apicomplexan parasites. Nature 451: 959-963.

Price, D. C., Chan, C. X., Yoon, H. S., Yang, E. C., Qiu, H., Weber, A. P. M., Schwacke, R., Gross, J., Blouin, N. A., Lane, C., ReyesPrieto, A., Durnford, D. G., Neilson, J. A. D., Lang, B. F., Burger, G., Steiner, J. M., Löffelhardt, W., Meuser, J. E., Posewitz, M. C., Ball, S., Arias, M. C., Henrissat, B., Coutinho, P. M., Rensing, S. A., Symeonidi, A., Doddapaneni, H., Green, B. R., Rajah, V. D., Boore, J., and Bhattacharya, D. (2012) Cyanophora paradoxa genome elucidates origin of photosynthesis in algae and plants. Science 335: 843-847.

Robinson, D. G. and Preston, R. D. (1971) Studies on the fine structure of Glaucocystis nostochinearum Itzigs. II. Membrane morphology and taxonomy. Br Phycol J 6: 113-128.

Sagan, L. (1967) On the origin of mitosing cells. J Theor Biol 14: 225-274.

Sato, M., Mogi, Y., Nishikawa, T., Miyamura, S., Nagumo, T., and Kawano, S. (2009) The dynamic surface of dividing cyanelles and ultrastructure of the region directly below the surface in Cyanophora paradoxa. Planta 229: 781-791.

佐藤蕆子, 豊岡公徳, 平田愛子, 南雲保, 河野重行 (2009) 最近の 研究と技術 ペプチドグリカン層をもつ葉緑体であるシアネレの 分裂と FtsZリング形成. 顕微鏡 44: 57-60.

Schnepf, E., Koch, W., and Deichgräber, G. (1966) Zur Cytologie und taxonomischen Einordnung von Glaucocystis. Arch Microbiol 55: 149-174.

Spiegel, F. W. (2012) Contemplating the first Plantae. Science 335: 809810.

Takahashi, T., Sato, M., Toyooka, K., Matsuzaki, R., Kawafune, K., Kawamura, M., Okuda, K., and Nozaki, H. (2014a) Five Cyanophora (Cyanophorales, Glaucophyta) species delineated based on morphological and molecular data. J Phycol 50: 1058-1069.

Takahashi, T., Sato, M., Toyooka, K., and Nozaki, H. (2014b) Surface ornamentation of Cyanophora paradoxa (Cyanophorales, Glaucophyta) cells as revealed by ultra-high resolution field emission scanning electron Microscopy. Cytologia 79: 119-123.

Takahashi, T., Nishida, T., Saito, C., Yasuda, H., and Nozaki, H. (2015) Ultra-high voltage electron microscopy of primitive algae illuminates 3D ultrastructures of the first photosynthetic eukaryote. Sci Rep 5: 14735 .

Weatherby, K., Murray, S., Carter, D., and Šlapeta, J. (2011) Surface and flagella morphology of the motile form of Chromera velia revealed by field-emission scanning electron microscopy. Protist 162: 142-153.

Willison, J. H. M. and Brown Jr., R. M. (1978) Cell wall structure and deposition in Glaucocystis. J Cell Biol 77: 103-119.

Winter, A. and Siesser, W. G. (1994) Coccolithophores. Cambridge Univ. Press, Cambridge.

Received: 18 December 2015 / Accepted: 30 December 2015 